\title{
EquiLIBRIUM
}

Quarterly Journal of Economics and Economic Policy

2015 VOLUME 10 ISSUE 1, March

p-ISSN 1689-765X, e-ISSN 2353-3293

www.economic-policy.pl

Wolska, G. (2015). The Review of Theories of Mainstream Economics on the Example of Economic Models. Equilibrium. Quarterly Journal of Economics and Economic Policy, 10(1), pp. 207-220, DOI: http://dx.doi.org/10.1 2775/EQUIL.2015.010

Grażyna Wolska*

University of Szczecin, Poland

\section{The Review of Theories of Mainstream Economics on the Example of Economic Models}

\section{JEL Classification: $E 10$}

Keywords: economic model; economics; economic theories; economy

\begin{abstract}
Regardless of the fact that economics distinguishes itself from other social sciences by a high level of formal deductive modelling, it is a social science due to the essence of the economic process where a human is a subject and an object at the same time. In recent years this issue has been more frequently emphasized by economists in ongoing discussions. In the discussions, a good deal of time is devoted to economic models and, mainly, their relations with the socioeconomic reality and coherence of empirical evidence. The article presents a thesis that some mainstream economic theories have not always constituted the background to their practical applications, which led - and still can lead-to the dogmatic and inflexible use of model solutions for economic phenomena which are difficult to forecast in a non-variant rigid model. The aim is to critically analyse the beliefs about the usefulness of universal economic models in the economic reality advocated by mainstream economists, and to prove that not all economic models have constituted the background to their practical applications.
\end{abstract} Toruń

(C) Copyright Institute of Economic Research \& Polish Economic Society Branch in

Date of submission: December 5, 2014; date of acceptance: February 3, 2015

* Contact: grazyna.wolska@wzieu.pl, University of Szczecin, Faculty of Management and Economics of Services, ul. Cukrowa 8, 71-004 Szczecin, Poland 


\section{Introduction}

The necessity of reviewing or even redefining some previous economic theories arose earlier. Nevertheless, these processes have been accelerated by the last global crisis. Then, practice visibly showed that some assumptions of theories of economics, including the mainstream theory, become invalid under the influence of the dynamically changing reality.

The article refers to the recent economic debates on the fallacy of the contemporary economic theory vis-à-vis the economic reality. The aim is to conduct a critical analysis of the mainstream economics' conviction that the universal models are useful in the economic reality and to prove that not all economic models have been chosen to become the background of their practical implementations.

Mainstream economics (also called neoclassical synthesis) is an attempt to combine different economic theories, mainly the elements of Keynesian theory and monetarism. It is still the most common economic mindset in the world. However, the achievements of mainstream economics are being heavily criticized. The criticism comes down to objections to the methodological sphere and not noticing and omitting close relations between economy and other areas of social life, assumptions about extreme rationality of economic entities, simplifying model analyses, as well as accepting by its followers the axiom of a perfect information flow and unlimited possibility of using it. Meanwhile, market reactions of economic entities appeared to be different from what in the theory of mainstream economics concerns standard models of a competitive market. Thus, basic dogmas of mainstream economics were criticised severely because they diverged significantly from the economic reality. The negation of the doctrines of mainstream economics caused that, in the 1970s and 1980s, some of its assumptions were liberalized. As part of moderating the assumptions of mainstream economics, above all new theoretical tools were applied which made it possible to analyse imperfectly competitive market structures and, especially, to use in the analysis the issues concerning the exchange of intermediate products, monopolistic competition, the meaning of economies of scales and activities of international companies.

L. Calmfors created a list of objections to economists, mainly followers of mainstream economics, among which there was a statement saying that these economists are not able to assess risks, their analyses are in general false, theories are not coherent and models break under their own weight or are incompatible with the reality (Walter, 2011, pp. 40-41). K. Juselius also treats economists, especially those being followers of neoclassical and mainstream economics, with a lot of reserve. In her view, econometrics is 
certainly a part of economics due to using tools of mathematics, statistics and informatics for studying the relations between phenomena in economy, but it is also used to conduct analyses and prepare economic forecasts. However, according to K. Juselius, authors of econometric models attach more significance to their mathematical and statistical precision (they are very often awarded the Nobel Prize for that) than to the reality in which they should be useful. What was mastered to perfection was creating a price index used to indicate an inflation index omitting such elements as a dramatic rise of stock and real estate prices or increasing exchange rates of the Swiss franc and other currencies. In economic models, however, many other factors are not considered, e.g. the widening gap between the rich and the poor, or the focus on results and maximum intensification of work, which causes stress and makes a circle of the excluded broaden. In consequence, they do not give answers to our questions which we need (Walter, 2011, pp. 40-41). The issue was emphatically raised by L.Calmfors mentioned before who claims that economists were the cause of the crisis and that: "(...) it is their extensive financial instruments, their policy of low interest rates and deregulation of the financial market that led to the collapse of the Lehman Brothers investment bank and, then, to the financial crisis of the global economy in autumn 2008" (Walter, 2011, pp. 40-41).

D. Orrell treats economics, especially the assumptions of mainstream economics, very disapprovingly. D. Orrell identifies mainstream economics with the following ten assumptions (which, incidentally, are accepted by the majority of economists): economy can be described using economic laws, it consists of independent entities, it is stable, rational and effective, it does not favour any sex, the economic risk can be managed thanks to statistics, economic growth can last forever and it is always good and gives us happiness (Orrell, 2010). In should be added that these assumptions serve as the basis for neoclassical economics and other currently dominating theories, among others the efficient-market hypothesis. According to D. Orrell, economics is in such a bad state because mainstream economists are Pythagoreans ${ }^{1}-$ from "an initiation" to an approach to forecasting. One becomes an economist through long and expensive (in the Anglo-Saxon countries) studies. There are strong mechanisms for extorting orthodoxy (in the main economic magazines, it is practically impossible to publish studies

\footnotetext{
${ }^{1}$ To put it simply: the Pythagoreans thought that the whole world can be described by numbers. Some, no mean - there were to be smooth, perfect numbers. They believed that there is some profound order which special people - those like them - are able to encapsulate in refined theories. Initiation meant that the Pythagoreans were a very elite circle. To join them, one had to meet high requirements: dispose of all possessions, lead an ascetic life and study for five years having taken a vow of silence.
} 
which challenge the aforementioned assumptions). Mainstream economists (as well as neoclassical ones) seek elegant numerical rationality. Just as Pythagoreans, they are willing to ignore inconvenient facts in order to sustain the belief that the economy looks as they would like it to look. The author claims also that mainstream economists try to imitate Newton (the fathers of modern macroeconomics - William Jevons Leon Walras or Vilfredo Pareto - were saying that straight), even though they deal with a completely different sphere of reality. Meanwhile, Newton understood that it is impossible to describe human behaviours in a way that physics does. He wrote: "I can calculate the motion of heavenly bodies, but not the madness of people." D. Orrell explains in an appropriate and accessible way why he criticizes the basic model of neoclassical economics, also accepted by mainstream economics. In his view, it does not correspond to human economy, but the god's, and he gives the following example: "If an economist knocked on your doors and asked you to create the plan of consumption for the rest of life, you could have quite a problem. (...) It would require unlimited computational capabilities" - he writes. Then, he points out that "Mainstream economics assumes that people are highly rational - superrational, and are not subject to emotions. They never overeat or get drunk, they save towards their retirement, the exact amount that is needed first, they count how much they will need and then, they save money with a meticulous precision. Real people are not like that" (Orrell, 2010).

Many economists being followers of modern mainstream economics have presented the achievements of economics in such a way as if it was a part of applied sciences. Such an approach, however, involves different research methods since a greater precision and ability to forecast are expected from applied sciences than from social sciences. It provokes some reflection that if a degree of methodology of some economic articles is comparable to studies from applied sciences, then one should be prepared that it increases the expectations concerning the insight and the accuracy of answers to many questions related to, among others the last crisis.

Summing up, it can be acknowledged that a big mistake of economic policy in the mainstream theory was universalism established a priori. As a result, mainstream economics has become excessively formalized. It limited economics to rigid and measurable dimensions which were very often included in economic models. Together with complex economic phenomena, such formalism led to mistakes involving a significant simplification of mechanisms functioning in economy. It is impossible to present essential qualitative features using algebraic formulas in economics. The next drawback of modern mainstream economics is assuming that in the economy there are "optimal" solutions which can be easily found as a result of the 
analysis of an adopted model. It is not possible because assuming that, one should exclude from the real world consumers' irrational behaviours, risk, speculations, enterprise and uncertainty connected with it, which take place in every real socioeconomic life.

The imperfections of mainstream economics presented above show awareness of the necessity for transformation in the theory of economics and socioeconomic practice, and, what is most important, support more extensive research and discussions on possible directions of changes.

\section{Methodology of the Research}

The scientific aim of the article requires an adequate methodology of research, which will allow to define efficacy and research value of the presented analysis.

The modern economics in its main trends (including main-stream economics) employs a perspective basing on statistical or mathematical methods. In order to obtain data necessary for such a methodology the supporters of the main-stream economics introduce statistical methods in their modified form, i.e. econometrics. This formal approach to economics has lead to a divide between economists focused on direct, practical aspects and the ones who stressed the importance of models created by means of new analytical tools. One has to point out that more often than not many authors have underlined the danger of "mathematization" of economics due to the formal approach or the scientism, i.e. the simplified attempts to uncritically adapt certain methods from so-called "natural sciences" to human or social sciences.

Taking all the above mentioned errors of the main-stream economics into account, the author based her methodological assumptions on the following axioms: the methodology employed in the research ought to include not only the research methods themselves (i.e. the choice and creation of the research acts) but also the conditions (psychological, sociological, technical) in order to obtain and formulate the knowledge and foremost the features expected from the knowledge worthy to be considered scientific. Therefore, the methodology nowadays should be seen in a wider scope, as a field encompassing not only the methods, but their results as well.

The methodology of economics, just like any other disciplinary methodology, has generated its specific methodological terms and criteria employed in the presented article. These criteria are mostly the following:

- Theoretical context/paradigm including the hitherto obtained research results (bibliography, social factors and individual motivations). 
- The scope of the reality taken under observation, convergence with socio-economic reality.

- The perspective of the research.

- Methodology (such as critical analysis of the bibliography, confrontation of the existing hypothesis and economic laws with the reality, monographic method, inductive method).

- The form of assertions (the terminological apparatus, language).

- Social needs triggered by the research.

\section{Controversies Over Economic Models}

Varied approaches towards issues concerning modelling in economics contributed to the development of numerous models, reasons for their divisions and types. In the Polish bibliography of economics, these issues were dealt with in a great deal of studies, parallel to papers in economics, econometrics, statistics and other fields close to economics.

"A model" from the perspective of economics is frequently defined as:

- "A simplified image, model of a part or a set of economic life" (Chodorowski, 1974, p. 81) $)^{2}$.

- "A set of assumptions of the economic theory that is a set of conditions where abstract laws are true" (Lange, 1959, pp.123-124).

- "A theory describing a copy of the original which retains the original's properties" (Nowak, 1972, p. 136).

- "A simplified image of economy. With the use of, e.g. a drawing, mathematical equations, a mechanical device, a model shows relations of studied variables" (Czarny, 2011, p. 66).

Obviously, there are many other interpretations of the term "economic model" in the Polish and also foreign literature on the subject, however, it seems that few quoted ones make it possible to state that an economic model is an ambiguously defined and relative concept. Since an economic model is explained as a simplified portray of a part of the economic reality, in such a case, in the structure of economics everything can be a model. Then, according to J. Semkow (1977, p. 152), a model is any economic concept because in its simplified form it shows key features of some elements of economic life. From this perspective, every economic theory is a model as well; this way some definitions of a model equate it with an economic theory. Despite this correct remark made by J. Semkow, a model in economics

\footnotetext{
${ }^{2}$ Many definitions concerning this point of view differ from each other because many of them equate the concept of a model with a theory.
} 
is frequently treated as a synonym of an economic theory, however, a model is more often a simplified schema of functioning of national economy or, in general, an economic phenomenon (Marciniak, 2007, p. 31).

Regardless of semantic disputes, an economic model always presents a narrowed image of the economic reality. It is impossible, however, to fully convey the economic reality through applying even extensive, complex and multidimensional models, since real economy undergoes a constant evolution caused by social, cultural, political, technical and technological changes, and also by natural disasters. Therefore, a lot of economic models are of a static nature. However, economic laws and theories in static relations cannot be equivalents for reality, since they involve specific context which does not appear in reality. They only copy objective regularities. Thus, models - mainly macroeconomic ones - are based on knowledge from the past. Meanwhile, economy undergoes a constant transformation.

Nevertheless, an economic model helps to create a synthetic image of regularities appearing in economy. Adopting essential assumptions which simplify the economic reality, one can create a model of economy and analyse undergoing in it relations between economic entities. Then, from a nature of these relations and regularities between them, the behaviour of entities in the economic reality can be deduced (Rekowski, 2005, p. 32). The issue was similarly presented by E. Stiglitz who claimed that "in every analysis there are used models which have a form of simple hypotheses concerning reactions of particular units and companies to different changes in a country's policy and a total influence of these reactions on economy. In order to illustrate consequences of various country's activities, everyone use models - politicians as well as economists. However, as opposed to politicians, in their models, economists try to form hypotheses very clearly, in such a way that they are not contradictory to each other and they are in accordance with reality" (Stiglitz, 2004, pp. 22-23). Reality showed that J. E. Stiglitz overestimated prudence and pragmatism of many economists. Moreover, he altered the aforementioned statement. At the economic conference in Lindau in Switzerland in 2012, in which seventeen economic Noble prize winners took part, he stated that macroeconomists have been ignoring undergoing changes for so long that they have lost contact with reality creating unreal economic models (Żakowski, 2011, p. 21) ${ }^{3}$.

According to J. E. Stiglitz (2004, pp. 22-23), economics, especially macroeconomics, for a few last decades has become a refined academic field, however not very useful in practice. Accuracy of this statement is proved by irregularities and even errors in the assessment of socioeconomic

\footnotetext{
${ }^{3}$ In the article, the author described a debate on modern economics which took place in Lindau and 17 economic Nobel prize winners took part in it.
} 
achievements (as the last global crisis revealed), both at the microeconomic (mainly in the evaluation of companies' assets prices and capitals value) and macroeconomic level (e.g. in the evaluation of the value of gross domestic product, GDP). The issue is described at length among others by R. Skidelsky, who claims that the global crisis was a result of a wide range of irregularities and errors in the evaluation of assets by private banks and rating agencies. The consequence of these irregularities was largely illusory models (Skidelsky, 2011). This situation has one more alarming side, that is, it provides impetus for marginalizing ethical and moral values. Thus, it is worth emphasizing that it is mainly the lack of obeying ethical rules that led not only to irregularities connected with the system of assessment of socioeconomic achievements, but also with the outbreak of the last crisis.

The economic crisis, situation on financial markets, bankruptcy of many banks and changes in consumer behaviour have given rise to a fierce discussion among economists which focused on the problems related to the socioeconomic theory and practice. The criticism mainly concerned the utilitarianism of models constructed by economists. There were many negative opinions, especially among macroeconomists, on the belief that there is a possibility of devising universal economic models that completely reflect the economic reality. One of the sceptics is P. Diamond ${ }^{4}$, who claims that each individual situation requires a different model, while some economists erroneously believe that once a mechanism or a truth are discovered they should be treated as indisputable. G. Akerlof aptly encapsulated this problem stating that the letter "e" which symbolizes real human behaviour in macroeconomic models has been replaced by "e*" that symbolizes how people should behave according to the author. It is G. Akerlof's opinion that the asterisk should be deleted and replaced by knowledge that stems from research on real human behaviour. In most cases such research has not been conducted yet (Żakowski, 2011).

T. Lawson $(2009$, pp. 757, 765) has also heavily criticised the relations between economic models and the socioeconomic reality and their coherence with empirical evidence. He completely negated the application of modelling as a useful method for assessment and recognition of the essence of the socioeconomic reality by claiming that such a reality has "depth or structure; the social relations, rules, positions, power structures and so forth that are typically immeasurable [...]. Social reality, in other words, is of a nature that is significantly at variance with the closed systems of isolated

\footnotetext{
${ }^{4}$ Peter Diamond is considered one of the most eminent modern economists together with Stiglitz, Krugman or Roubini.
} 
atoms that would guarantee the conditions of mathematical deductivist modelling".

In its nature, the construction of models that reflect the economic reality as accurately as possible is a difficult and complicated task. Many economists state that creating an economic model often verges not only on science but also on art. It is difficult not to agree with such a statement. Building a model that includes all indispensable features of the real world from the perspective of researched problems is not so easy, especially when at the same time it cannot include too many or too little details. An impressive number of variables and their interdependencies in the former case make the essence of the problems disappear in the swath of data. While, in the latter case the simplification will result in a general outline of the analysed aspect and, in consequence, it will not allow to accurately and comprehensibly present the researched problem. Incidentally, the term "art of economics" dates back to J.N. Keynes who divided economics into positive and normative and was later cited by M. Friedman. J. N. Keynes did not create such a division because in reality he divided economics into positive, normative and the art of economics. He emphasised that the art of economics is of a great importance as it is the branch of economics that also concerns economic policy. Therefore, the art of economics requires a judgement regarding reality as it introduces sociological and political variables. According to D. C. Colander, it is inevitable when we talk about economic policy. He elaborates on the topic saying: "the main objection I have to the majority of people in our profession is that they try to combine positive economics with economic policy and draw conclusions about it from models which are not realistic enough from the institutional perspective to be used for such aims" (Snowdon \& Vane, 2003, pp. 284-285).

M. Friedman argued that the realism of assumptions is irrelevant and that, what is really important, is the prognostic value of a theory (Snowdon \& Vane, 2003, p. 284). D. C. Colander absolutely rejects this notion and claims that everything is dependent on the level of deliberation. According to D. C. Colander, there is no method in macroeconomics to unquestionably test all devised concepts at an empirical level. The author emphasizes that "[...] where you cannot test empirical theorems, the method based on "prognostic value" becomes problematic. There is no proven theory in macroeconomics. We only perceive reality in a general way. The realism of assumptions in such a general understanding of reality plays the main part as assumptions constitute a part of this understanding. The assumptions determine what is perceived. Thus, I believe that Friedman is completely wrong in his view of macroeconomics, however, in a wider sense, if we assume that economics was a science in which one can unambiguously test 
theorem, I would be more willing to approve of Friedman's views" (Snowdon \& Vane, 2003, p. 284).

Considering the above deliberations, it appears there is a considerable group of modern economists that firmly emphasize the significance of qualitative factors in their final conclusions on economic models. Meanwhile, the neoclassical theory, and later mainstream economics, radically divided the quantitative and qualitative manifestations of phenomena, which in practice disregarded the role of qualitative aspects. Thus, the constructed econometric models omitted qualitative elements which could not be included as variables in a model because they were considered immeasurable. As a result, discerning cause and effect relations between individual elements of economy became more complicated as the qualitative manifestations of phenomena and economic processes were disregarded. Economics thereby moved away from real social problems while attempting to gain an image close to the one possessed by applied sciences. In consequence, quantitative analysis methods became of a great importance in mainstream economics as they allowed the balance of each particular element of the economic system to be accurately described. Economists started to be solely interested in aspects that were measurable, countable and could be mathematically expressed.

Naturally, neither theoretical concept nor economic model can ideally recreate the complexities of socioeconomic life. It is necessary to apply a simplified image that concentrates on recurring, representative manifestations of phenomena and processes. Thus, the purpose of a model is not to reproduce reality accurately, but to retain the realism of its assumptions.

\section{Basic Premises and the Potential of Behavioural Economics}

The conducted analysis of the theory of mainstream economics from the perspective of economic models allows a following conclusion to be formulated: the most often framed reproof of economic models concerned their inaccuracy with the reality of economy. The criticism was also aimed at too much theory in economic models, as well as at an excess of empirical knowledge. According to A. Wojtyna (2009, pp. 36-37), as well as other participants of this discussion, a major part of objections to mainstream economics would lose its strength [...] "if new findings of research conducted on human behaviour by other disciplines (mainly by psychology and neurophysiology) were taken into account to a larger extent." In other words, mainstream economics would be more receptive to behavioural 
economics ${ }^{5}$, which in recent years without doubt has become one of the most dynamically developing research areas in economics". It is a very accurate insight, as behavioural economics is currently perceived as a mature research programme and a separate sub-discipline of economics. D. Fudenberg (2006) points out that the outcome of such research was not only attracting the mainstream economic followers' attention to the irregularity of human behaviour that deviates from a standard model, but mainly building formalized models which generate and explain these irregularities and may be incorporated into larger models. Nevertheless, behavioural economists realize that, on the one hand, their accomplishments cannot be questioned, but, on the other hand, they are aware that an unquestioned introduction of their own research programme may lead to them being excluded from the discourse. This happened to heterodox economics which also presented different research methods and subject of analysis in comparison with mainstream economics, though in a more forceful manner. Mainly, but not only, due to those reasons, relations between mainstream economics and behavioural economics are still weak. In a long-term perspective, according to C. F. Camerer and G. Loewenstein, simplified models based on the assumption of strict rationality will be successively replaced by behavioural models. The assumption of strict rationality, which currently is perceived as an inherent part of economics, in the future will be treated as a useful, special case that stems from more general, behaviourally-substantiated theory (similarly to how the Cobb-Douglas production function or the expected value maximization principle are treated now). At the same time, they emphasize that their approach is not based on an idea of a complete rejection of neoclassical economics, which in general is very useful, but "on modification of one or two assumptions of the standard

\footnotetext{
${ }^{5}$ Inception or rather origins of behavioural economics can be dated back to the 1930s. John Broadus Watson and Burrhus Frederic Skinner are considered the founders of behavioural economics. In 1979, however, texts by Daniel Kahneman and Amos Tversky in Prospect Theory: An Analysis of Decisions under Risk were published. It was followed by Richard Thaler's Toward a Positive Theory of Consumer Choice a year later (Kahneman \& Tversky 1979, pp. 313-327; Thaler 1980, p. 39-60). Both of these publications triggered a rapid development of a new field known as behavioural economics. In their works, the authors explained economic theories in the context of psychological basis for human behaviour. Behavioural economics is not a homogenous school, quite the contrary, it consists of a set of different theories including the Michigan School (George Katona), psychological economics (Colin Camerer, Richard Thaler, Ernst Fehr), behavioural macroeconomics (George Akerlof), evolutionary economics (Richard Nelson, Sidney Winter), behavioural finances (Robert Schiller) or experimental economics (Vernon Smith). What all these concepts have in common is the negation of neoclassical convictions that equate a human with homo oeconomicus whose characteristics are absolute rationality, drive to satisfy only their own narrowly defined interest and complete self-control.
} 
theory in order to achieve a higher psychological realism" (Camerer, Loewenstein, 2004; Wojtyna, 2009, p. 41). Table 1 shows the main characteristics of mainstream economics and behavioural economics.

Table 1. The main characteristics of mainstream economics and behavioural economics

\begin{tabular}{|l|l|}
\hline \multicolumn{1}{|c|}{ MAINSTREAM ECONOMICS } & \multicolumn{1}{|c|}{ BEHAVIOURAL ECONOMICS } \\
\hline $\begin{array}{l}\text { Mainstream economics, also referred to as } \\
\text { neoclassical synthesis, is an attempt to } \\
\text { combine various economics theories, mainly } \\
\text { the elements of Keynesian economics and } \\
\text { monetarism. }\end{array}$ & $\begin{array}{l}\text { Behavioural economics is a discipline that } \\
\text { combines the accomplishments of classical } \\
\text { economics and psychology. It is a field of } \\
\text { an economic analysis that verifies the as- } \\
\text { sumptions of neoclassical economics on the } \\
\text { basis of sociological and psychological } \\
\text { research findings. }\end{array}$ \\
\hline $\begin{array}{l}\text { Main research methods: econometric model- } \\
\text { ling, deductive and abstract methods, the } \\
\text { analysis of economic phenomena from the } \\
\text { static and dynamic perspectives, taking into } \\
\text { account innovation in built models, devising } \\
\text { microeconomic base for a macroeconomic } \\
\text { analysis that guarantees internal coherence. }\end{array}$ & $\begin{array}{l}\text { Main research methods: the theory of } \\
\text { planned behaviour, experiments that employ } \\
\text { more realistic psychological foundations. }\end{array}$ \\
\hline
\end{tabular}

Source: own work.

Thus, agreement, consensus or shared beliefs so much needed by modern economies are a procedural content of conditions on which the success of mainstream economics being receptive to behavioural economics depends. However, the success depends on whether the assumptions used in mainstream economic models will be supplemented with qualitative factors. This means that they will also include the ideas of behavioural economics mainly including assumptions that are based on sociological and psychological research findings, as well as the findings of research that apply a similar methodology. As A. Wojtyna (2009, p. 47) noted, this will support making "economic human" resemble "ordinary humans". The future will show whether and to what extent these changes will be useful in practice. However, due to increasing criticism of models that are often defined as the standard models of mainstream economics, certainly there is a natural need to search for new solutions focused on the usability of economic models in real economy, especially in terms of their forecasting capabilities. This thesis is proved by the fact that none of the intricately built economic models forecasted the crisis. Although, more worrying is the fact that there have not been built any models that would show how to get out of it. 


\section{Conclusions}

This article has presented the position which claims that for mainstream economics to assertively open up to behavioural economics there is a need for the advocates of the former to be always reflective, think critically and search, as well as to overcome their persistence of adhering to one right ideology, because it blocks the way to complementary changes in economics. Therefore, many economists (including Phelps) claim that the emergence of new, practical solutions is only a matter of time. It is, however, difficult to say whether the new axioms will emerge in the following years or whether it is a thing for the next generations possessing more advanced knowledge and technology. Probably just as in the preceding years or epochs we will be observing a clash of opinions between the way or continuation, rationalization, resignation or introducing total changes. Surely, for most of the economists the choice will come down to a fundamental rationalization of the hitherto theories and the alternative based on new theoretical grounds. A proof of that stands on the determination of many economists thriving towards deep changes.

\section{References}

Camerer, C. F., Loewenstein, G. (2004). Behavioral Economics: Past, Present, Future. In: Camerer, C. F., Loewenstein, G., Rabin, M. (eds.). Advances in Behavioral Economics. Princeton: Princeton University Press.

Camerer, C. F., Loewenstein, G., Rabin, M. (eds.) (2004). Advances in Behavioral Economics. Princeton: Princeton University Press.

Czarny, B. (2011). Podstawy Ekonomii. Warsaw: PWE.

Fudenberg, D. (2006). Advancing Beyond Advances in Behavioral Economics. Journal of Economic Literature, 3. http://dx.doi.org/10.1257/jel.44.3.694.

Chodorowski, J. (1974). Definicje w Systemach Ekonomicznych. Wrocław: PWN.

Lange, O. (1959). Ekonomia Polityczna. Tom I, Warsaw.

Lawson, T. (2009). The Current Economic Crisis: Its Nature and the Course of Academic Economics. Cambridge Journal of Economics, 33(4). http://dx.doi. org/10.1093/cje/bep035.

Marciniak, S. (ed.). (2007). Makro- i Mikroekonomia. Podstawowe Problemy. Warsaw: PWN.

Nowak, L. (1972). Model Ekonomiczny. Studium z Metodologii Ekonomii Politycz$n e j$, Warsaw: PWN.

Orrell, D. (2010). Econonomyths . Ten Ways Economics Gets It Wrong as in: K. Nędzyński, Ekonomia Głównego Nurtu jest Ideologią, nie Nauką. Retrieved from: http://www.obserwatorfinansowy.pl/forma/rotator/ekonomia-glownegonurtu-jest-ideologia-nie-nauka/ (16.08.2014). 
Ratajczak, M. (2011). Co dalej z Ekonomia? In: M. Bochenek (Eds.). Studia z Historii Ekonomii. Toruń: Polskie Wydawnictwo Ekonomiczne Oddział w Toruniu.

Rekowski, M. (2005). Mikroekonomia. Poznań: WROKOPA Sp. z o.o.

Semkow, J. (1977). Rola Modeli w Dociekaniach Ekonomicznych. Warsaw: Biul. Nauk. Inst. Nauk Ekonomicznych.

Skidelsky, R. (2011). Democracy Or Finance, Project Syndicate. Retrieved from: http://www.skidelskyr.com/site/article/democracy-or-finance (18.04.2011).

Snowdon, B., Vane, H.R. (2003). Rozmowy z Wybranymi Ekonomistami. Warsaw: Polskie Towarzystwo Ekonomiczne, Dom Wydawniczy Bellona.

Stiglitz, J. E. (2004). Ekonomia Sektora Publicznego. Warsaw: Wydawnictwo Naukowe PWN.

Thaler, R. (1980). Toward A Positive Theory of Consumer Choice. Journal of Economic Behavior and Organization, 1. http://dx.doi.org/10.1016/01672681(80)90051-7.

Tversky, A. (1979). Prospect Theory: An Analysis of Decisions under Risk. Econometrica, 47.

Walter, T. (2011). Mocni w gębie. Polityka, 46 (2833).

Wojtyna. A. (2009). Wspótczesna Ekonomia - Kontynuacja czy Poszukiwanie Nowego Paradygmatu. In: B. Fiedor, Z. Hockuba (Eds.). VIII Kongres Ekonomistów Polskich, Nauki Ekonomiczne Wobec Wyzwań Współczesności. Warsaw: Polskie Towarzystwo Ekonomiczne.

Żakowski, J. (2011). Najwybitniejsi ekonomiści świata są bezradni. Polityka, 36. 